\title{
DISTURBANCES IN SLEEP PATTERNS OF PATIENTS UNDERGOING GASTROINTESTINAL ONCOLOGICAL SURGERY
}

\author{
DISTÚRBIOS NO PADRÃO DO SONO EM PACIENTES SUBMETIDOS À CIRURGIA \\ ONCOLÓGICA GASTROINTESTINAL
}

\section{Guilherme Abner Sousa ALMEIDA ${ }^{1}$; Nathália Silva GOMES ${ }^{2}$; Maria Helena BARBOSA ${ }^{3}$; Elizabeth BARICHELLO ${ }^{4}$}

1. Enfermeiro. Mestre em Atenção a Saúde, Universidade Federal do Triângulo Mineiro - UFTM, Uberaba, MG, Brasil; 2. Mestre em Atenção a Saúde, Doutoranda do Programa de Pós Graduação Stricto Sensu em Atenção à Saúde da UFTM, Uberaba, MG, Brasil; 3. Doutora em Enfermagem na Saúde do Adulto, Professora Associada do Curso de Graduação em Enfermagem e do Programa de Pós Graduação Stricto Sensu em Atenção à Saúde da UFTM, Uberaba, MG, Brasil; 4. Doutora em Enfermagem Fundamental, Professora Associada do Curso de Graduação em Enfermagem e do Programa de Pós Graduação Stricto Sensu em Atenção à Saúde da UFTM, Uberaba, MG, Brasil. lizabarichello@ hotmail.com

RESUMO: Objetivo: avaliar o padrão do sono em pacientes com câncer submetidos à cirurgia oncológica gastrointestinal e relacioná-lo com as dimensões de qualidade de vida. Método: estudo transversal com abordagem quantitativa, realizado com 114 pacientes. Foram utilizados os instrumentos sociodemográfico e clínico, Índice de Qualidade do Sono de Pittsburg (PSQI) e o European Organization for Research and Treatment of Cancer Quality of the Questionnaire Core 30 (EORTC QLQ-C30). Resultados: a maioria era do sexo masculino, tinham entre 50 e 60 anos, aposentados, casados, estudo fundamental incompleto. O câncer na porção colorretal foi predominante, período do pósoperatório de até dois meses e com tempo de diagnóstico de até seis meses. A dor, o tempo da cirurgia e do diagnóstico foram preditivos para os distúrbios do sono, influenciando negativamente na qualidade deste. As correlações entre o PSQI e o EORTC-QLC-C30 foram significativas para todas as dimensões das escalas funcionais e para a Escala Global de Sintomas (EGS). Quanto maior o escore das escalas funcionais do EORTC-QLC-C30 e do EGS, melhor a qualidade de vida, enquanto um escore elevado do PSQI indica pior qualidade do sono. Os indivíduos que apresentaram dor tiveram escores mais elevados do PSQI, o que indica pior qualidade do sono, ainda, quanto menor o tempo de realização da cirurgia e do tempo do diagnóstico, maior é o escore do PSQI, ou seja, padrão do sono ruim. Conclusão: os cuidados prestados aos pacientes com câncer requerem que a equipe de enfermagem tenha conhecimento dos sintomas gerados pelo tratamento, visando que a sobrevivência a esta doença venha acompanhada de uma boa qualidade de vida.

PALAVRAS-CHAVE: Enfermagem oncológica. Transtornos do sono. Qualidade de vida. Neoplasias gastrointestinais.

\section{INTRODUCTION}

Cancer, or the formation of a neoplasm, consists in the abnormal proliferation of tissue that runs partially or fully out of control and tends to gain autonomy and perpetuation, with harsh effects to the host body (BRASIL, 2015b).

Among the various types of cancer is the gastrointestinal cancer, with colorectal and stomach cancer being the most incident. Esophagus, pancreas, liver and oropharynx cancer, despite being less incident, are also associated with the gastrointestinal system (BRASIL, 2011).

With regard to treatment modalities, there are three main ways: chemotherapy, radiotherapy and surgery. They can be used together, depending on the susceptibility of tumors to each of the therapeutic modalities and on the best sequence of administration (BRASIL, 2012a).

With respect specifically to surgery, patients are not always prepared and informed about the complexity of the treatment and its effects, which may directly influence the quality of life (MELLO et al., 2010).

Whereas the quality of life is the perception of their position in life, in the context of culture and in the system of values in which they live and in relation to their goals, their expectations, their standards and their concerns (WHOQOL GROUP, 1994), it is important that treatments be presented to the patient, showing the impact of each one of these to aid patients in choosing the type of treatment to be adopted (BARICHELLO, 2008).

Sleep disturbances are a common and often chronic problem of patients with several types of cancer diagnosis, reported by up to $72 \%$ of these patients. Trouble to fall asleep, trouble in staying asleep and poor sleep quality are the main manifestations of these disorders (ROSCOE et al., 2007; BERGER, 2009; PALESH et al., 2009; OTTE et al., 2010).

Despite the high incidence, sleep disorders are rarely reported to the health team. It is, therefore, necessary that the nurse or the doctor 
inquire the patient about this symptom, to be resolved as soon as possible (GRACI, 2005).

Thus, taking into consideration that 600,000 new cases of cancer, with nearly 180,000 cases of non-melanoma skin cancer and 420,000 new cases of other types (BRASIL, 2015a), are reported for the biennium 2016-2017, research on the subject becomes necessary in order to ensure and assist in maintaining a good quality of life for this population.

Thus, the goal of this study was to evaluate the pattern of sleep in patients with cancer in postoperative gastrointestinal oncological surgery and relate them to dimensions of quality of life.

\section{MATERIAL AND METHODS}

This cross-sectional study with quantitative approach is a portion of the master's thesis of the Graduate Program Strictu Sensu in Health Care, Federal University of Triangulo Mineiro (UFTM), entitled "Disturbances in sleep patterns and fatigue in patients undergoing gastrointestinal oncological surgery" developed at the Oncological Clinic at the Hospital Hélio Angotti, located in Uberaba- Minas Gerais (MG ).

Data collection was carried out from March to June 2013. The study population consisted of 114 patients diagnosed with oropharyngeal, esophageal, stomach, liver, pancreas and colorectal cancer who underwent surgery and who met the following inclusion criteria: having medical diagnosis of some kind of gastrointestinal cancer; be in the postoperative state for one month to one year; be in outpatient return; be 18 years old or older; be in physical and psychological conditions to attend the interview.

The study was approved by the Research Ethics Committee of UFTM, on October 26th 2011, under opinion N. 2015, complying with the resolution 196/96 on research involving human beings.

Collect data involved a daily search conducted in the medical records of patients scheduled for consultation in order to identify those who had some type of gastrointestinal cancer. The patients identified were approached for interview by the researcher in the waiting room of the hospital clinic.

Three instruments were used for data collection: the first related to socio-demographic and clinical data of the patient (previously submitted to a committee of experts to apparent and content validation); the second was the Pittsburg Sleep Quality Index (PSQI) and, finally, the European
Organization for Research and Treatment of Cancer Quality of the Questionnaire Core 30 (EORTCQLQ-C30). Both the PSQI and the EORTC-QLQC30 were validated for the Brazilian population: the first one by Ceolim (1999) and the latter by Brabo et al., (2006).

The PSQI measures the subjective quality of sleep for the occurrence of its disorders and consists of ten questions that comprise seven components. The sum of the maximum score of the instrument is 21 points, with scores above five points indicating poor quality of sleep pattern (CARDOZO, 2011).

The EORTC-QLQ-C30 has 30 issues with scale ranging from zero to 100 and consists of Global Health Scale (ESG), Functional Scale (EF) and Symptom Scale (ES) formed by different dimensions or domains. For calculation of each scale, the mean score is used (SCHROETER, 2011).

Data were entered into an electronic sheet in the program Excel XP ${ }^{\circledR}$ of Microsoft ${ }^{\circledR}$ and loaded in the program Statistical Package for Social Sciences (SPSS) version 20, for processing and analysis.

Statistical analysis for qualitative variables included frequency measures and for bivariate analysis, contingency tables. For quantitative variables, measures of position and variability were used.

The relationship between the scores of quality of life and quality of sleep and quantitative variables was estimated through Pearson correlation index.

A multivariate linear regression model was fitted to assess possible risk factors associated with sleep quality. The value of 0.05 was assumed as probability of error of the first type considered statistically significant.

The internal consistency of PSQI and of EORTC-QLQ-C30 was evaluated through the Cronbach's alpha coefficient, considering results with alpha over 0.70 to be satisfactory.

This study is part of research project entitled Quality of life in patients with cancer and had financial support (APQ-02411-14) from the Fundação de Amparo à Pesquisa de Minas Gerais (FAPEMIG).

\section{RESULTS}

The study sample consisted of 114 individuals, and the predominant age group was 50 60 years $(31.6 \%)$, followed by people between 60 and 70 years $(30.7 \%)$, median of 59.5 years. Most respondents were male $(64.9 \%)$. Retirees/pensioners had higher frequency $(47.4 \%)$. Regarding marital 
status, $49.1 \%$ were married and $86 \%$ reported living with a partner.

Most respondents had incomplete primary education (64.9\%) and monthly income from one to two minimum wages $(34.2 \%)$. Regarding the origin, $49.1 \%$ lived in Uberaba and $50.9 \%$ in other cities. Most lived in urban areas $(86.8 \%)$.

Cancer in the colorectal portion had the higher prevalence $(52.6 \%)$, followed by stomach (16.7\%), oropharynx (15.8\%), esophagus $(7.0 \%)$, liver $(4.4 \%)$ and, pancreatic cancer had the lowest (3.5\%). In addition, $62.3 \%$ of respondents did not undergo chemotherapy and/or radiotherapy in the preoperative period, but $73.7 \%$ did so postoperatively. The predominant postoperative period was up to two months (21.9\%) with time of diagnosis of up to six months (40.4\%).

The Cronbach's alpha for the PSQI was 0.75, indicating high internal consistency. Among 114 patients, 100 (87.7\%) had overall score of PSQI above five points, indicating poor sleep quality.

According to Table 1, the most frequent time to lie was between 21 and 23 hours (55.3\%). Most $(37.7 \%)$ said they take 16-30 minutes to fall asleep and 19 (16.7\%) said they take more than 60 minutes. As for the time of waking up, predominated the times between six and seven (46.5\%), although 51 (44.7\%) sleep an average of seven to eight hours per night.

Table 1. Sleep pattern of patients with gastrointestinal cancer in the postoperative period. Uberaba, MG, 2013.

\begin{tabular}{lccc}
\hline \multicolumn{1}{c}{ Questions } & Answers & $\mathrm{F}$ & $\%$ \\
\hline What time did you go to sleep? & $19-21 \mathrm{~h}$ & 15 & 13.1 \\
& $21-23 \mathrm{~h}$ & 63 & 55.3 \\
& $23-1 \mathrm{~h}$ & 32 & 28.1 \\
& $1-3 \mathrm{~h}$ & 4 & 3.5 \\
\hline How long (in minutes) does it take for you to fall & $\leq 15 \mathrm{~min}$ & 30 & 26.3 \\
asleep? & $16-30 \mathrm{~min}$ & 43 & 37.7 \\
& $31-60 \mathrm{~min}$ & 22 & 19.3 \\
& $>60 \mathrm{~min}$ & 19 & 16.7 \\
\hline What time do you wake up in the morning? & $4-5 \mathrm{~h}$ & 6 & 5.3 \\
& $5-6 \mathrm{~h}$ & 18 & 15.8 \\
& $6-7 \mathrm{~h}$ & 53 & 46.5 \\
\hline How many hours of sleep do you sleep per night? & $>7-7 \mathrm{~h}$ & 35 & 32.4 \\
\hline & $7-8 \mathrm{~h}$ & 51 & 30.7 \\
& $8-9 \mathrm{am}$ & 15 & 44.7 \\
& $9-10 \mathrm{~h}$ & 8 & 13.1 \\
\hline
\end{tabular}

Source: Data collected by the authors (2013).

The analysis of the seven components of the PSQI showed that the sleep disorder (1.75) was the most influent for the poor sleep quality. Few patients reported the use of medication to sleep (0.83) and this component had, therefore, the lowest average.

As for subjective sleep quality (1.47), most (49.1\%) patients rated their sleep quality as good, but $27(23.7 \%)$ classified it as bad and 19 (16.7\%) as very bad.

The analysis of the questions of the PSQI relating to the daytime dysfunction (1.58) showed that $44(38.6 \%)$ patients reported having problems, with a frequency of three times a week or more, to stay awake while driving, making meals or participating in any other social activity. In addition, $64(56.1 \%)$ reported feeling a little or moderately unwell and lacking enthusiasm to perform daily activities (Table 2).

The principal problems of the quality of sleep were: taking longer than 30 minutes to fall asleep (59.6\%), waking up in the night or in the morning very early $(71.1 \%)$ and getting up to go to the bathroom $(59.6 \%)$ with frequency of three times a week or more.

As for the habit of napping, 84 (73.3\%) said they do it, and of these, 51 (60.7\%) dozed intentionally. Those who consider the act of dozing a need add $56(66.6 \%)$.

Correlations between the PSQI and the EORTC-QLC-C30 were significant for all dimensions of functional scales and the GSS. Table 3 shows that the correlation was negative, that is, the higher the score of functional scales EORTC-QLC- 
C30 and GSS, the better quality of life, while a high

PSQI score indicates worse sleep quality.

Table 2. Measures position and variability of the components of sleep in post-surgical patients with gastrointestinal cancer. Uberaba, MG, 2013.

\begin{tabular}{lccccc}
\hline \multicolumn{1}{c}{ PSQI } & Min. & Max. & Mean & Median & Standard deviation \\
\hline Subjective sleep quality & 0 & 3 & 1.47 & 1.0 & 0.89 \\
Sleep latency & 0 & 3 & 1.65 & 2.0 & 1.33 \\
Sleep time & 0 & 3 & 1.48 & 2.0 & 0.89 \\
Habitual sleep efficiency & 0 & 3 & 1.28 & 1.0 & 0.97 \\
Sleep disorders & 0 & 3 & 1.75 & 2.0 & 0.77 \\
Use of medication for sleep & 0 & 3 & 0.83 & 0.0 & 1.31 \\
Daytime dysfunction & 0 & 3 & 1.58 & 2.0 & 0.99 \\
PSQI global score & 0 & 20 & 10.04 & 10,5 & 4.56 \\
\hline
\end{tabular}

Source: Data collected by the authors (2013).

In the symptom scale, only nausea and vomiting and constipation showed no statistically significant correlation. The other dimensions of symptom scales were positively correlated with the
PSQI. The higher the PSQI score, the greater will also be the scores of symptom scales, which indicates limited quality of life (Table 3).

Table 3. Correlation between the global PSQI score and domains of EORTC-QLC-C30 of postsurgical patients with gastrointestinal cancer. Uberaba, MG, 2013.

\begin{tabular}{llcc}
\hline \multicolumn{1}{c}{ Scale } & \multicolumn{1}{c}{ Domains of EORTC-QLC-C30 } & i & P \\
\hline PSQI (Global) & GSS & $-0.53^{* *}$ & 0.000 \\
& Physical function (PF) & $-0,27^{* *}$ & 0.004 \\
& Role performance (RP) & $-0,27^{* *}$ & 0.004 \\
emotional function (EF) & $-0,38^{* *}$ & 0.000 \\
& Cognitive function (CF) & $-0,43^{* *}$ & 0.000 \\
Social Function (SF) & $-0,32^{* *}$ & 0.000 \\
& Fatigue (FAT) & $0.49^{* *}$ & 0.000 \\
Nausea and vomiting (NAV) & 0.11 & 0.233 \\
Pain & $0,30^{* *}$ & 0.001 \\
Dyspnea (DIS) & $0.29^{* *}$ & 0.002 \\
& Insomnia (INS) & $0.69^{* *}$ & 0.000 \\
& Loss of appetite (LAP) & $0.28^{* *}$ & 0.002 \\
& Constipation (CON) & 0.07 & 0.427 \\
& Diarrhea (DIA) & $0.23^{* *}$ & 0.012 \\
& Financial difficulties (FD) & $0.23^{* *}$ & 0.014 \\
\hline
\end{tabular}

$* \mathrm{P}<0.05$. ** $\mathrm{P}<0.01$; Source: Data collected by the authors (2013).

In order to identify the predictors of sleep disorders, the variables age group, sex, pain, postoperative treatment, surgery time and time of diagnosis were inserted in the multivariate linear regression model. Three independent predictors were identified for sleep disorders: pain, surgery time and diagnosis time.
As indicated in Table 4, individuals who experience pain $(p=0.068)$ had higher scores of PSQI, which indicates worse sleep quality. It was also observed that the shorter time of the surgery $(\mathrm{p}$ $=0.000)$ and shorter the time of diagnosis $(\mathrm{p}=$ 0.013) implies higher PSQI score, that is, bad sleep pattern.

Table 4. Logistic regression model for sleep disorders. Uberaba, MG, 2013.

\begin{tabular}{llll}
\hline Variable & & $\boldsymbol{\beta}$ & $\mathbf{P}$ \\
\hline Fatigue & No & Ref. & - \\
& Yes & 0.104 & 0.151 \\
Age group & Adult & Ref. & - \\
& Elderly & 0.025 & 0.719
\end{tabular}




\begin{tabular}{llll} 
Gender & Male & Ref. & - \\
\multirow{2}{*}{ Pain } & Female & 0.106 & 0.134 \\
& No & Ref. & - \\
Post-operative treatment & Yes & 0.137 & $0.038^{*}$ \\
& No & Ref. & - \\
Surgery time & Yes & -0.098 & 0.163 \\
& Within 6 months & Ref. & - \\
& More than 6 & -408 & $0,000 *$ \\
Time of diagnosis & months & & - \\
& Within 6 months & Ref. & $0.013 *$ \\
& More than 6 & -0.267 & \\
\hline
\end{tabular}

*Statistically significant; Ref = Reference value; Source: Data collected by the authors (2013).

\section{DISCUSSION}

Males were predominant in this study, corroborating another study by Mello et al. (2010). At the same time, this is at odds with INCA estimates for the biennium 2016-2017, in which the incidence of new cases in women is higher (BRASIL, 2015a).

Colorectal cancer has risk factors some lifestyle habits such as diet rich in red meat and low intake of fruits / vegetables and vegetables, overweight and obesity, physical inactivity, alcohol consumption and smoking, and genetic predisposition and age (BRASIL, 2015a). According to the Surveillance of Risk and Protective Factors for Chronic Diseases through Telephone Survey (VIGITEL), the percentage of male that are smokers in Brazil was $18.1 \%$ and women, $12 \%$. Among those who smoke 20 cigarettes or more per day, $5.4 \%$ were men and $3.3 \%$ women. As for the abusive consumption of alcohol, the rate was three times higher in men $(26.2 \%)$ than in women (9.1\%) (BRASIL, 2012b), what contradicts that alcohol consumption and smoking are related to sex, for this type of cancer.

In a survey of patients with colorectal cancer, advanced age or equal to 50 years was predominant $(60.4 \%)$ just as observed in this study where there was a predominance of ages $50+60$ $(31.6 \%)$ and $60+70$ years $(30.7 \%)$ (CHAVES; GORINI, 2011). Increase rates with increasing age is observed both in incidence and mortality (BRASIL, 2015a).

The fact that most patients have not completed primary education indicates a low level of education among participants. The study by Pedruzzi et al. (2011), showed that the low level of education of cancer patients causes a delay in the perception of the signs and symptoms of the disease and hence delay in seeking medical care, delays in diagnosis and decreased therapeutic possibilities.
Colorectal cancer was slightly predominant (52.6\%) compared to the others types (stomach cancer, followed by the oropharynx, esophagus, liver and pancreas). With respect to colorectal cancer, this data goes against the estimate of the National Cancer Institute for the biennium 20162017 (BRASIL, 2015a).

The neoadjuvant chemotherapy or radiation therapy has been increasingly used because it reduces the size of the tumor for improved ease of resection. According to Andreollo et al. (2013), in a study with 123 patients that had esophageal cancer and underwent esophagectomy, those who underwent neoadjuvant chemotherapy or radiotherapy had higher survival than those who only underwent surgical treatment. In this study, $37.7 \%$ of patients with gastrointestinal cancer had some kind of pre-operative treatment.

The value found for the average global PSQI score (10.04) was indicative of poor sleep quality. Other studies obtained similar results: 7.7 in elderly patients with cancer under outpatient chemotherapy and 12.00 in patients with advanced cancer (MYSTAKIDOU et al., 2007;_SCHLOSSER, 2011). In another study, $73.9 \%$ had an overall score higher than five (BARICHELLO et al., 2009).

The aspects that are somewhat related to the sleep disorder component were the most influent on the poor quality of sleep in patients, reaching the higher score (1.75). Detailed analysis of factors that contributed to the sleep disorder called attention to waking up in the middle of the night or very early in the morning $(71.1 \%)$, taking more than 30 minutes to fall asleep (59.6\%) and getting up to go to the bathroom (59.6\%). In the research by MansanoSchlosser e Ceolim (2012) showed that the need to get up to go to the bathroom (83.6\%) and waking up in the middle of night or very early in the morning (47.9\%) as the main problems that led patients to the sleep disorder 
Mansano-Schlosser and Ceolim (2012) point out the importance of knowing the factors that lead to sleep disorders to better target interventions and guidelines to be planned and implemented together, not isolated, by health professionals (MANSANO-SCHLOSSER; CEOLIM, 2012). It is known that the incidence of sleep disorders in people with cancer is about $30 \%$ to $50 \%$, while in the general population this percentage is around 15\% (BARICHELLO et al., 2009), what reinforces the importance of these interventions.

The component sleep latency (time to fall asleep), score of 1.65, had the second highest score. As evidenced, 59.6\% said they take more than 30 minutes to fall asleep and this happens three or more times a week. In other studies, patients with cancer said to take an average of 25 to 30 minutes to fall asleep. The scores of sleep latency in these studies ranged from 0.96 to 1.3 (MANSANOSCHLOSSER; CEOLIM, 2012; PHILLIPS et al., 2012). In the study by Mystankidou et al. (2007) with patients with advanced cancer, the score for this component was 2.4.

As for duration of sleep (1.48), 30.7\% sleep four to seven hours per night. Although there is no perfect consensus on the number of hours slept per night. Mansano-Schlosser and Ceolim (2012) studying sleep patterns in patients with cancer have found an average of 6.96 hours of sleep per night. In another study, $30.7 \%$ slept five hours or less per night (SCHLOSSER, 2011). In patients with advanced cancer, the score for duration of sleep was 2.0 (MYSTAKIDOU et al., 2007).

The patient's perception of quality of sleep (subjective sleep quality) reached the scores of 1.47, but the majority classified it as good (49.1\%). Phillips et al. (2012) found a score of 1.13 for this question, even though $18 \%$ have responded good and $56 \%$ very good for sleep quality. This finding highlights the need for a more comprehensive assessment of the sleep pattern of cancer patients, since the symptoms are overlooked in the clinical approach of the patient.

Quality bad and very bad was reported by $40.4 \%$ of patients. In a survey by Flynn et al. (2010), participants expressed concerns about the importance of sleep to fight cancer. They often felt apprehensive about the potential negative impact that poor sleep could have on their health, fearing that this may contribute to a higher risk of recurrence and progression of cancer.

The use of medication to sleep (0.83) had the lowest average among the components, as well as in other studies (MANSANO-SCHLOSSER; CEOLIM, 2012; PHILLIPS et al., 2012). According to Phillips et al. (2012), sleep disorders can go undetected and, thus, untreated in patients taking medication for sleep. Roizenblatt et al. (2012) showed that the use of sedative and sleep inducing drugs is seen as negative because they result in lack of attention or drowsiness during the day, what in turn could increase fatigue and muscle pain and reduce the pain threshold.

The analysis of questions of the PSQI related to nap is suggestive of daytime sleepiness and disorders during the day and indicates daytime dysfunction (1.58). When sleep disorders are present, changes in mood and enthusiasm for performance of routine activities can happen, causing daytime disorders (BARICHELLO et al., 2009). In this study we believe that daytime disorders in this population may be evidenced by the need of the habit to take a nap, even intentionally.

Schlosser (2011) states that a more detailed, targeted and not superficial evaluation is necessary (sleep good or bad, quality of sleep good or bad) with respect to aspects that represent potential losses to the sleep quality of cancer patients. In addition, interventions and guidelines to be planned by health professionals are better designed when aware of specific factors that incur disturbance to nighttime sleep.

The sleep pattern showed a statistically significant correlation with almost all areas of the EORTC-QLC-C30. This finding emphasizes the relationship between the already known sleep disorders and quality of life studied by several national and international authors (ROSCOE et al., 2007; MYSTAKIDOU et al., 2007).

The quality of sleep was associated with the presence of pain, so that patients who reported pain had poor sleep. Pain is a major symptom faced by cancer in both, patients undergoing treatment and patients who are at an advanced stage of the disease. Additionally, surgery may further increase the intensity of pain in these patients. It is notable that the combination pain, sleep disturbances and fatigue are reported by more than $40 \%$ of cancer patients (ROIZENBLATT et al., 2012). In another study, the presence of pain in cancer elderly was not associated with sleep quality. There was an increase of $21 \%$ in the chance of the patient to present poor sleep for each point on the scale of pain (SCHLOSSER, 2011).

In the multiple linear regression, the variables time of diagnosis and surgery time were inversely associated with the PSQI. The longer the time of diagnosis and surgery, the better the quality of sleep. With the rehabilitation of post-surgical patients, physical function tends to improve, 
promoting better quality of life and consequently improvement in sleep quality. It is expected that the time of diagnosis decrease the whirlwind of emotions, worries about health and fear of death that affect patients in the early stages, and that may negatively influence their sleep.

A limitation of this study was the crosssectional cut because it was not possible to evaluate sleep pattern over time and the evolution of quality of life. However, the use of instruments to investigate the pursued questions were effective and can be used in clinical practice. Despite these limitations, the results corroborate other studies, emphasizing the importance of research of this nature.

This study allowed us to evaluate the disturbances in sleep patterns in patients undergoing gastrointestinal oncological surgery and relate them to the dimensions of quality of life. The pain, the time of surgery and the time of diagnosis were predictive for sleep disorders, negatively influencing the quality of sleep. The most relevant hindering factors of quality of sleep were: taking longer than 30 minutes to get to sleep, waking up in the middle of the night or very early in the morning and get up to go to the bathroom. Correlations between the PSQI and the EORTC-QLC-C30 were significant for all dimensions of functional scales and for the GSS. The higher the score of functional scales of EORTC-QLC-C30 and GSS, the better quality of life, while a high PSQI score indicates worse sleep quality. Individuals who experienced pain had higher PSQI scores indicating worse quality of sleep. Moreover, the shorter the time of the surgery and the time of diagnosis, the greater the PSQI score, that is, poor sleep pattern.

Few works are published on this topic. Therefore, by pointing out the domains of sleep and quality of life mostly affected may contribute to the planning of nursing interventions for the management of these symptoms and, above all, improve the quality of life of these patients.

Thus, the care given to people with cancer requires quality of care and that the multidisciplinary health team have knowledge on the biological and physical processes of the disease and the symptoms generated by the existing treatments, in order that survival may come along with good quality life.

\begin{abstract}
Objective: to evaluate the sleep pattern in cancer patients undergoing gastrointestinal oncological surgery and relate it to the dimensions of quality of life. Method: cross-sectional study with quantitative approach performed with 114 patients. Sociodemographic and clinical instruments, the Pittsburg Sleep Quality Index (PSQI) and the European Organization for Research and Treatment of Cancer Quality of the Questionnaire Core 30 (EORTC QLQ-C30) were used. Results: most patients were male, aged between 50 and 60 years, retired, married, with incomplete primary school. Cancer in colorectal portion was predominant, postoperative period up to two months and time of diagnosis up to six months. The pain, the time of surgery and the time of diagnosis were predictive for sleep disorders, negatively influencing the quality of sleep. Correlations between the PSQI and the EORTC-QLC-C30 were significant for all dimensions of functional scales and the Global Scale of Symptoms (GSS). The higher the score of functional scales of EORTC-QLC-C30 and GSS, the better quality of life, while a high PSQI score indicates worse sleep quality. Individuals who experienced pain had higher PSQI scores indicating worse quality of sleep. Moreover, the shorter the time of the surgery and the time of diagnosis, the greater the PSQI score, that is, poor sleep pattern. Conclusion: the care of cancer patients requires awareness from the nursing staff about the symptoms generated by the treatment, with the purpose that the survival in face of this disease may come along with good quality of life.
\end{abstract}

KEYWORDS: Oncologic nursing. Sleep disorders. Quality of life. Gastrointestinal neoplasms.

\title{
REFERENCES
}

ANDREOLLO, N. A. et al. Neoadjuvant chemoradiotherapy and surgery compared with surgery alone in squamous cell carcinoma of the esophagus. Arquivos de Gastroenterologia, São Paulo, v. 50, n. 2, p. 101106, Apr./June, 2013. https://doi.org/10.1590/S0004-28032013000200016

BARICHELLO, E. et al. Quality of sleep in postoperative surgical oncologic patients. Revista LatinoAmericana de Enfermagem, Ribeirão Preto, v. 17, n. 4, p. 481-488, July./Aug. 2009. 
BERGER, A. M. Update on the state of the science: sleep-wake disturbances in adult patients with cancer. Oncology Nursing Forum, New York, v. 36, n. 4, p. 165-177, July 2009. https://doi.org/10.1188/09.onf.e165e177

BRABO, E. P. et al. Brazilian version of the QLQ-LC13 lug cancer module of the Europen Organization for Researh and validaty report. Quality of Life Research, Oxford, v. 15, n. 9, p. 1519-1524, Nov. 2006. https://doi.org/10.1007/s11136-006-0009-9

BRASIL. Ministério da Saúde. Secretaria de Atenção à Saúde. Instituto Nacional de Câncer. ABC do câncer: abordagens básicas para o controle do câncer. Rio de Janeiro: INCA, 2012a. Disponível em: < http://www1.inca.gov.br/inca/Arquivos/livro_abc_2ed.pdf>. Acesso em: 15 set. 2013.

BRASIL. Ministério da Saúde. Secretaria de Atenção à Saúde. Instituto Nacional de Câncer. Estimativa 2012: incidência de câncer no Brasil. Rio de Janeiro: INCA, 2011. Disponível em: < http://portal.saude.sp.gov.br/resources/ses/perfil/gestor/homepage/estimativas-de-incidencia-de-cancer2012/estimativas_incidencia_cancer_2012.pdf>. Acesso em: 9 ago. 2013.

BRASIL. Ministério da Saúde. Secretaria de Atenção à Saúde. Instituto Nacional de Câncer. Estimativa 2016: incidência de câncer no Brasil. Rio de Janeiro: INCA, 2015a. Disponível em: < http://www.inca.gov.br/bvscontrolecancer/publicacoes/edicao/Estimativa_2016.pdf>. Acesso em: 20 dez. 2015.

BRASIL. Ministério da Saúde. Secretaria de Atenção à Saúde. Instituto Nacional de Câncer. Manual de bases técnicas da oncologia - SIA/SUS - Sistema de Informações Ambulatoriais. Rio de Janeiro: INCA, 2015b. Disponível em: < http://www1.inca.gov.br/inca/Arquivos/manual_oncologia_13edicao_agosto_2011.pdf>. Acesso em: 13 dez. 2015.

BRASIL. Ministério da Saúde. Secretaria de Vigilância em Saúde. Vigitel Brasil 2011: vigilância de fatores de risco e proteção para doenças crônicas por inquérito telefônico. Brasília, DF, 2012b. Disponível em: < http://bvsms.saude.gov.br/bvs/publicacoes/vigitel_brasil_2011_fatores_risco_doencas_cronicas.pdf $>$. Acesso em: 10 set. 2013.

CARDOZO, F. M. C. A influência da depressão e fadiga na qualidade de vida dos pacientes oncológicos submetidos à quimioterapia. 2011. 79 f. Dissertação (Mestrado em Enfermagem) - Escola de Enfermagem, Universidade de São Paulo, Ribeirão Preto, 2011.

CEOLIN, M. F. Padrão de atividade e de fragmentação do sono em pessoas idosas. 1999. 287 f. Tese (Doutorado em Enfermagem) - Escola de Enfermagem, Universidade de São Paulo, Ribeirão Preto, 1999.

CHAVES, P. L.; GORINI, M. I. P. C. Qualidade de vida do paciente com câncer colorretal em quimioterapia ambulatorial. Revista Gaúcha de Enfermagem, Porto Alegre, v. 32, n. 4, p. 767-773, 2011.

FLYNN, K. E. et al. Sleep-wake functioning along the cancer continuum: focus group results from the patientreported outcomes measurement information system (PROMISTM). Psycho-Oncology, New York, v. 19, n. 10, p. 1086-1093, 2010. https://doi.org/10.1002/pon.1664

GRACI, G. Phatogenesis and manegement of cancer-related insomnia. The Journal of Supportive Oncology, Huntington, v. 3, n. 5, p. 349-359, Sept./Oct. 2005.

MANSANO-SCHLOSSER, T. C.; CEOLIM, M. F. Qualidade de vida de pacientes com câncer no período de quimioterapia. Texto \& Contexto Enfermagem, Florianópolis, v. 21, n. 3, p. 600-607, July/Sept. 2012. https://doi.org/10.1590/S0104-07072012000300015

MELLO, B. S. et al. Pacientes com câncer gástrico submetidos à gastrectomia: uma revisão integrativa. Revista Gaúcha de Enfermagem, Porto Alegre, v. 31, n. 4, p. 803-811, 2010. https://doi.org/10.1590/S198314472010000400026 
MYSTAKIDOU, K. et al. The relationship of subjective sleep quality, pain and quality of life in advanced cancer patients. Sleep, New York, v. 30, n. 6, p. 737-742, 2007.

OTTE, J. L. et al. Prevalence, severity and correlates of sleep-wake disturbances in long-term breast cancer survivors. Journal of Pain and Symptom Management, Madison, v. 39, n. 3, p. 535-547, 2010. https://doi.org/10.1016/j.jpainsymman.2009.07.004

PALESH, O. G. et al. Prevalence, demographics and psychological associations of sleep disruption in patients with cancer: University of Rochester Cancer Center- Community Clinical Oncology Program. Journal of Clinical Oncology, New York, v. 28, n. 2, p. 292-298, 2010. https://doi.org/10.1200/JCO.2009.22.5011

PEDRUZZI, P. A. G. et al. Perfil epidemiológico dos pacientes com câncer de cabeça e pescoço que evoluíram a óbito antes de receber tratamento. Revista Brasileira de Cirurgia de Cabeça e Pescoço, São Paulo, v. 40, n. 2, p. 57-60, 2011.

PHILLIPS, K. M. et al. Characteristics and correlates of sleep disturbances in cancer patients. Supportive Care in Cancer, Berlin, v. 20, n. 2, p. 357-365, 2012. https://doi.org/10.1007/s00520-011-1106-z

ROIZENBLATT, M. et al. Pain-related diseases and sleep disorders. Brazilian Journal of Medical and Biological Research, Ribeirão Preto, v. 45, n. 9, p. 792-798, 2012. https://doi.org/10.1590/S0100879X2012007500110

ROSCOE, J. A. et al. Cancer-related fatigue and sleep disorders. The Oncologist, Dayton, v. 12, p. 35-42, 2007. https://doi.org/10.1634/theoncologist.12-S1-35

SCHLOSSER, T. C. M. Qualidade do sono e fadiga em idosos sob tratamento quimioterápico ambulatorial. 2011. 121 f. Dissertação (Mestrado em Enfermagem) - Faculdade de Ciências Médicas, Universidade Estadual de Campinas, Campinas, 2011.

SCHROETER, D. Validação e reprodutibilidade de dois questionários específicos para avaliação da qualidade de vida de pacientes com câncer de ovário. 2011. 154 f. Dissertação (Mestrado em Ciências) Faculdade de Saúde Pública, Universidade Federal de São Paulo, São Paulo, 2011.

WHOQOL GROUP. Development of the WHOQOL: rationale and current status. International Journal of Mental Health, Philadelphia, v. 23, n. 3, p. 24-56, 1994. https://doi.org/10.1080/00207411.1994.11449286 